\title{
XXIX. An abstract of the characters of Ochsenheimer's Genera of the Lepidoptera of Europe; with a list of the species of each genus, and reference to one or more of their respective icones
}

\author{
J.G. Children F.R.S. L.\&E. F.L.S.
}

To cite this article: J.G. Children F.R.S. L.\&E. F.L.S. (1829) XXIX. An abstract of the characters of Ochsenheimer's Genera of the Lepidoptera of Europe; with a list of the species of each genus, and reference to one or more of their respective icones, Philosophical Magazine Series 2, 5:27, 188-195, DOI: $10.1080 / 14786442908674959$

To link to this article: http://dx.doi.org/10.1080/14786442908674959

曲 Published online: 14 Jul 2009.

Submit your article to this journal $₫$

ЦIl Article views: 2

$Q^{\mathbf{2}}$

View related articles \lceil 
Petite Ourse dans ses deux passages." Or, c'est là précisement l'étoile qu' a donné cette anomalie inexplicable et inexpliquée de 3 à 4 secondes. Faudra-t-il donc revenir aux soupçons de feu M. Méchain, qui ont fait les tourmens de derniers jours de sa vie, qui l'ont abreuvé d'amertumes, et qui l'ont précipité dans le tombeau?

XXIX. An Abstract of the Characters of Ochsenheimer's Genera of the Lepidoptera of Europe; with a List of the Species of each Genus, and Reference to one or more of their respective Icones. By J. G. CHILdREN, F.R.S. L. \& E. F.L.S. \&c.

[Continued from page 126.]

\section{Genus 42. GASTROPACHA, Ochs.*}

Lasiocampa, Schrank, Latr.

Odenesis, Lasiocampa, Clisiocampa, Curtis.

Gastropacha, Eutricha, Odonestis, Lasiocampa, Pecilocampa, Cnethocampa, Eriogaster, and Clisiocampa, Stephens.

Obs. Ochsenheimer remarks that this genus embraces, in fact, several groups well distinguished by peculiar characters,

yet

* In the twenty-third Number of his Illustrations of British Entomology, published on the first of this month (February, 1829), Mr. Stephens has introduced some further divisions of certain of the preceding genera of Ochsenheimer, which we take the earliest opportunity of communicating to our readers.

1. Genus Fumea, Haworth, adopted to receive the five following species, separated from Schrank's Genus PsYcHE, as given by Ochsenheimer; viz. nitidella, pulla, muscella, bombycella? and pectinella.

"Fumea, Haw.

" Palpi and maxilla wanting, their place occupied by a tuft of hairs. $A n$ tenne of the male elongate, bipectinated, the pectinations subclavate, ciliated and straight; of the female very short, simple, the two basal joints largest: head pilose anteriorly : thorax slightly hairy, and generally glossy : abdomen of the -male pilose, with a tuft at the apex; of the female more robust, with a woolly mass at the tip : wings incumbent, of the male diaphanous, deeply ciliated, pilose; of the female wanting: legs rather stout, the posterior tibiae very pilose, with elongate spurs at the apex. Larva inclosed in a case, in which it changes to pupa."-Steph. Illust. Brit. Ent. Haust. II. p. 81.

2. Genus Nudalata, Haworth, adopted to receive the three species, mundana, hemerobia and senex, separated from the Lithosice of Fabricius, I atreille and Ochsenheimer.-Stephens's second species, hemerobia, Hübn. is quoted by Ochsenheimer as synonymous with mundana.

"Nudaria, Haw.

" Palpi minute, curved upwards, squamous, triarticulate, the two basal joints of equal length, the terminal minute, cylindric: maxilla longer 
Ochsenheimer's Genera of the Lepidoptera of Europe. 189

yet so passing into one another, that he did not think fit to divide them into separate genera. He accordingly merely marked the several groups, by the imaginary family lines, $\mathrm{A}, \mathrm{B}$, and $\mathrm{C}$, without assigning other names to any of them than the general one, Gastropacha, which he adopted in consequence of a pretty universally pre-

vailing

than the head. Antenne simple in both sexes, ciliated beneath in the males : the basal joint robust, elongate, with a dense hairy tuft : head with a dense fascicle of hairs between the antennæ : thorax not crested: abdomen pilose, slender in the males, with a tuft at the apex; more robust in the femsles, the tip rather conical: wings slightly deflexed, more or less elongate, rounded posteriorly, diaphanous, pilose : legs rather slender, naked, the two posterior joints with spurs at the tip. Larva exposed, hairy: pupa obtuse."-Steph. l. c. II. p. 83.

Nudaria is distinguished "from the rest of the Arctiida (except Hypercompa) by the length of its maxillæ, which considerably exceeds that of the head."-Steph. l.c.

3. Genus Heterogenea, Knoch. The only species which Stephens records under this genus is asellas, (Hepialus asellus, Fab.)-It is not included by Ochsenheimer with his Hepiali, nor can I find it introduced by him, any where else.

“Heterogenea, Knoch.

" Palpi minute, densely clothed with scales, triarticulate, the second joint longest, the last minute: maxille wanting. Antenna of the female simple, slightly pubescent at the tip, with a small tuft of hairs at the end: head slightly hairy : thorax and abdomen scaly: wings opaque, scaly : anterior subtriangular, acute; posterior suborbiculate : legs rather slender; posterior tibice short, robust, with rather long spurs at the apex. Larva ovate, without legs, naked, depressed: pupa folliculated. Differs from Limacodes by the form of the anterior wings, which are trigonate, and somewhat truncated posteriorly."-Steph. l.c. p. 84.

4 .Genus Limacodes, Latreille. This is the last of the Arctiidæ; and the species, testudo, the only cne which Stephens places in it, is also a Hepialus of Fabricius, and like the last, not noticed by Ochsenheimer.

"Limacones, Latr.

“ Palpi short, a little ascending, densely clothed with scales and short hairs, triarticulate, basal joint short, second as long as the other two, robust, subcylindric, terminal, the length of the first, slender, subfusiform, slightly acute: maxilla obsolete. Antennce simple, of the male stout, compressed, rather serrated, pilose at the apex, of the female slender, a little serrated towards the apex, which is acute: head moderate, very hairy : thorax stout: abdomen slightly robust, a little tufted in both sexes at the apex, rather stoutest in the female: wings opaque, deflexed: anterior elongate, subtrigonate, posterior margins rounded: legs very stout, short; fenora and tibia with a broad fringe of hairs; anterior tibia simple, four posterior with spurs at the apex. Larva very stout, naked, limaciform, gibbous above, flat beneath, apodous : pupa robust, obtuse, posteriorly acute ; inclosed in a dense ovate folliculus.-Limacodes differs from Heterogenea at first sight by the stoutness of its thorax and abdomen, the elongation and rotundity of its anterior wings, and the robustness of its antennæ; the proportions and comparative bulk of the palpi, and other less evident characters." Steph. l. c. p. 85. 
vailing character; viz. the remarkable thickness of the abdomen of the female moth, deriving the term from the

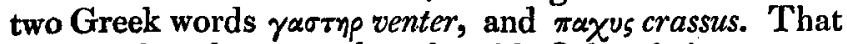
other authors have not thought with Ochsenheimer, as to the propriety of creating new genera and new names, is pretty evident, from the list of synonyms immediately preceding these observations; and in the present instance they seem to be right.

Fam. A. - Antenne bipectinate; palpi porrected; wings dentated; anterior deflexed; posterior projecting beyond the anterior when at rest; haustellum, none: larva flat beneath, convex above, semirugose; second and third segments with one or two transverse bands, and a conical tubercle on the penultimate, and similar shaped, tufted tubercles on the sides: metamorphosis above ground, in a rather long web covered on the inside with a whitish powder.

Species.

Icon.

1. G. Ilicifolia, Linn.* Ernst, IV.PI.CLXVIII. f.219. a. b.

2. - Betulifolia, Ochs. Ernst,IV.Pl.CLXVIII.f.220.a-k.

3. - Populifolia, Fab. Ernst, IV. Pl. CLXVII. f. 218.

4. - Quercifolia,Linn.*Ernst, IV. Pl. CLXVI. f. 217. a-g.

Curtis, I. Pl. 24. Imago et larva.

5. G. Alni-

5. Genus Calcimorpha, Latreille. This genus and Lrthosia, Latr. form each a part of Ochsenheimer's genera Lithosia, and Eyprepia. Mr. Stephens places Callimorpha at the head of his first family of the nocturnal Lepidoptera, the Lithosiidæ ${ }^{2}$, and arranges under it the two British species Jacobrea and Miniata: (Lithosia, Jacobcea, and Rosea, Ochs.)

"Callimorpha, Latr.

" Palpi short, a little descending or horizontally porrected, slightly hairy, triarticulate, the basal joint elongate-ovate, as long as the two following, which are of equal length, and subovate or attenuated, with the terminal one acute: maxillae longer than the head. Antenna setaceous, slightly ciliated in the males: head small, rathet hairy in front: thorax and abdomen clothed with silken scales; the latter somewhat robust in the female, slightly tufted in the male: wings rather broad, anterior elongate-trigonate, with the hinder margin rounded or subelliptic: legs moderate; tibia short, the posterior with two pair of spurs. Larva sparingly covered with hairs, or densely pilose, the head nearly naked: pupa obtuse or acute."-Steph. Illust. Brit. Ent. Haust. II. 89.

* Gasthopacha, Steph.

"Palpi elongate, porrected, hairy, triarticulate, the second joint longest;

a Consisting of the genera Callimorpha, Eulepia, Deiopeia, Lithosia, Gnophia, and Setina, as stated in the tabular view of the family, p. 89. 
Species.

5. G. Alnifolia, Ochs.*

6. - Pini, Linn. †......

7. - Pruni, Linn.......
Icon.

Ernst, IV. PI. CLXX̄. f. 222. a-h. Pl. CLXXI. f. 222. i-o.

Einst, IV. Pl. CLXIX. f. 221. a-g.

Fam. B. The two following species are placed in this division, as connecting the first and third families, Gastr. potatoria being nearly allied in its characters to the species of the family A. and G. lobulina to those of family C. Ochsenheimer gives no separate characters for this division.

the terminal obtuse: maxille very small. Antenne short, recurved, strongly bipectinated in both sexes: head small, with an acute, projecting hairy tuft : thorax and abdomen robust, densely pilose, the latter acute in the female: wings dentated, reversed during repose: legs moderately stout: the femora and tibice pilose. Larva broad, rounded above, with fascicles of hair on the sides, each segment with a fleshy lateral appendage, and on the penultimate joint a distinct truncated tubercle: pupa obtuse, inclosed in an oblong, broadly constructed co. coon and covered with a whitish powder." - Steph. Illust. Brit. Ent. Haust. II. p. 52.

* Gastr. alis reversis, subdentatis, cuprinis, strigis undatis, nigris.(Ochs. IV. p. 205.)

$\uparrow$ Odonesis, Curtis; Eutricha, Hübn. Steph.

"Palpi not very long, porrected, triarticulate, two basal joints of equal length, terminal more slender and obtuse : maxillae short, a little spiral. Antenne nearly straight, not very short, deeply bipectinated in the maies to the apex, which is a little bent; slightly bipectinated in the females: head small; thorax robust, densely pilose: abdomen the same, rather elongate; more robust in the females: wings, anterior entire, rounded pusteriorly; posterior obsoletely denticulated, reversed during repose: legs rather slender, not very pilose, with minute spurs at the apex of the tibiæ. Larva cylindrical, with fascicles of hairc down the sides, and a tubercular eminence on the penultimate joint: pupa short, obtuse, inclosed in an elongate, subfusiform, loosely-constructed cocoon."-Steph. Illust. Brit. Entom. Haust. II. p. 50.

Curtis's generic characters agree, of course, almost exactly with Stephens's, except as regards the middle joint of the palpi, "twice the length of either of the others," which is one of the principal characters assigned by Stephens as a reason for separating Bo. Pini, Linn., from Odonestis, the type of which genus, both according to Curtis and Stephens, is Bo. potatoria, Linn. Curtis also doubts the existence of maxilla and mandibles. His description is accompanied, as usual, with a beautiful plate (vol. i. Pl. 7.) on which is represented the figure of a male perfect insect, taken at Norwich, and that of the female caterpillar, copied from Roësel, together with figures of the dissected antennæ and palpi, magnified. 
Species.

Icon.

8. G. Potatoria, Linn.* Ernst, V. Pl. CLXXII. f. 223. $a-h$.

9. — Lobulina, Fab. ... Hübn.Bomb.Tab.41.f.180.(mas.) 181. (fom.)

FaM. C. Antenne bipectinate, in the male, very strongly, more slightly in the female: haustellum very small: roings entire, deflexed; the anterior with one or two transverse bands, and generally a white spot near the middle of the disc. Larva covered with short hairs, resembling pelt; when touched it rolls itself up: metamorphosis; the first species changes in a rigid cylindrical cocoon; the last in a soft, rather elongated web.

10. G. Trifolii, Hübn. †. Ernst, V. Pl. CLXXVI. f. 226. a. b. e.

11. - Medicaginis, Borkh.†Ernst, V. Pl. CLXXVI. f. 226. c. d. f. g. i.

Curtis, Brit. Ent. IV. pl. 181. Imago et larva.

12. G. Quercus,

* Odonesis, Curtis.-Odonestis, Germar. Steph.

"Palpi elongate, porrected, hairy, triarticulate, the basal joint not half as long as the second, the terminal rather larger than the basal, obtuse : maxillae obsolete. Antennce slightly curved near the base, bipectinated, especially in the males, to the apex: head small : thorax stout, loosely, but thickly pilose; abdomen the same, elongated, and tufted at the apex in the males, somewhat acute and stout in the females: wings reversed when at rest; anterior rather acute at the tip, the posterior margin rounded, entire; posterior slightly denticulate: legs stout, densely pilose, especially in the niales, with spurs at the apex of the tibiæ. Larva robust, cylindric, with fascicles of hair down the sides, a distinct tuft on the neck, and another placed on a minute tubercle on the penultimate joint: when alarmed it rolls itself in a ring : pupa robust ; obtuse, placed in a fusiform, closely woven, luteous cocoon." -Steph. Illust. Brit. Ent. Haust. II. p.51.

† Lasrocampa, Schrank, Curtis, Stephens, Leach.

" Antennce inserted towards the hind part of the head, nearly straight, setaceous, strongly bipectinated in the males, each branch being ciliated and producing a rigid bristle near the apex, inclining upwards : serrated in the females: maxille and mandibles none.

" Palpi 2, small, shurt, hairy; 3-jointed, 1st and 2nd joints robust; the former the longest; 3rd minute, ovate. Males smaller than the females.

"Head short. Eyes small. Thorax large, not crested. Abdomen of the males attenuated and divided at the apex; robust and subovate in the females. Wings entire, deflexed when at rest. Tarsi 5-jointed. Claws and pulvilli distinct.

"Caterpillars 
Species.

Icon.

12. G. Quercus, Linn.*... Ernst, V. Pl. CLXXIV. f. 225.

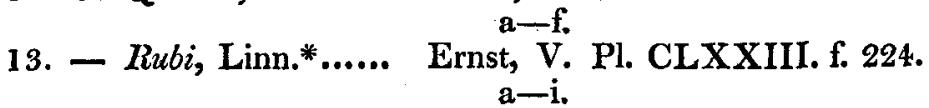

FaM. D. Antennce bipectinated, pectinations in the male very broad: wings not densely covered with scales; abdomen pilose, with black and yellow bands. Larva slightly hairy, with two rows of black spots on the back : do not roll themselves up when disturbed: metamorphosis, subterranean, without any web.

14. G. Taraxici, Fab.... Hübn. Bomb.Tab.37.f.165.(mas.) 166. (fœm.)

15. - Dumeti, Linn.† ... Ernst, V. Pl. CLXXVII. f. 227. a-g.

FaM. E. Antennee curved, finely pectinated in the male, scarcely perceptibly so in the female: roings detlexed, the anterior generally with two transverse bands, and occasionally a small, bright spot. Abdomen hairy; generally terminated, in the female by a dense tuft of soft hairs, with which she covers her eggs. Haustellum none. Larva elongated, slightly hairy, gregarious when young: metamorphosis, above ground in an oval cocoon.

Obs. Ochsenheimer, on Hübner's authority, subdivides this family into three sections, but gives no distinctive cha-

"Caterpillars with 6 pectoral, 8 abdominal, and 2 anal feet; cylindrical and hairy, curling themselves up when disturbed.

"Pupce inclosed in an obtuse, oblong cocoon of very close texture." Curtis, Brit. Ent. IV. p. 181.

Curtis assigns the following characters as distinctive of the three genera Gastropacha, Odonestis, and Lasiocampa; including the two former in one section, the last in another.

A. Palpi long. Inferior wings when at rest projecting beyond the costa of the superior. Larve not cylindric, having fascicles of hair down the sides, and a dorsal tubercle near the apex. Cocoons long, attenuated, silky and soft.

a. Antenne curved. Tongue short. Wings denticulated.

Gastropacha.

b. Antenne straight. Tongue none. Wings not denticulated.

ODONESTIS.

B. Palpi minute. Inferior wings not projecting when at rest. Larva cylindric, clothed with hairs. Cocoons oblong, obtuse, dense and rigid in texture,

* Lasiocampa, Curtis, \&c. Lasiocampa.

N. S. Vol. 5. No. 27. March 1829.

$\uparrow$ Lasiocampa, Steph. 2 C racters 
racters for either, which, he says, are better obtained by description of the separate species respectively, than they can be collectively, from the groups.

Species.

Icon:

16. G. Populi, Linn.*... Ernst, V. Pl. CLXXXIII. f. 236. a-g.

17. - Cratagi, Linn.†.. Ernst, V. Pl. CLXXXII. f. 235. a-e.

18. - Processionea, Linn. ${ }_{+}^{+}$Ernst, V. Pl. CLXXXIV. f, 238. a-f.

19. - Pityocampa, Fab. $\ddagger$ Ernst, V. PI. CLXXXIV. f. 239. $a-f$.

20. - Catax, Linn....... Ernst, V. Pl. CLXXVIII. f. 229.

a-e.

- Pecilocampa, Steph."

"Palpi extremely minute, subglobose, enveloped in slender elongate hairs: maxille obsolete. Antenna densely bipectinated in the males, the pectinations scarcely decreasing towards the apex; strongly serrated in the females: head very small, and hairy: thorax stout and hairy : abdomen abbreviated, tufted in the male, and pilose laterally in both sexes, the female without a downy mass at the apex : wings entire, elongate, acute, subdiaphanous, not reversed during repose : legs with the femora and tibia pilose. Larva slightly hairy, a little depressed, maculated, not gregarions : pupa short, obtuse, inclosed in a silken folliculus, superficially subterranean."-Steph. Illust. Brit. Ent. Hanst. II. 43.

+ Crislocampa, Curtis.-See Gen. Char., Species 25. G. castrensis; note.

$\ddagger$ CNethocampa , Steph.

"Palpi very short, envéloped in longish hairs, triarticulate, the basal joint longer, and stouter than the second, terminal minute, slender, rather acute: maxilla obsolete. Antenna short, slightly curved, bipectinated in the males, serrated in the females, tlee pectinations gradually decreasing in length to the apex: head distinctly visible from above: thorax stout, hairy : abdomen rather elongate, tufted, the apex of the female with a woolly mass : wings slightly reversed, obscurely diaphanous : cilia not abbreviated: legs slender: femora and tibize pilose. Larva gregarious, cylindrical, hairy : pupa also gregarious, obtuse, bidentate posteriorly, inclosed in a rigid cocoon." - Steph. Illust. Brit. Ent. Haustel. II. 46.

From Poctlocampa and Eriogaster (a genus to be presently noticed); Cnethocampa differs by the tenuity and shortness of the antennæa and their pectinations in the nuales, and by the downy tuft at the apex of the abdomen, in the females; and from the latter genus both sexes differ by the elongation of the cilia, exclusively of differences in the trophi, \&c. "The habits of the larvæ are also remarkably dissimilar to those of the above genera; and their hairs, when applied to any part of the body, cause very great irritation and acute pain, especially those of Cn. Pityoeampa."-Steph. l. c.

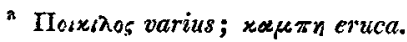

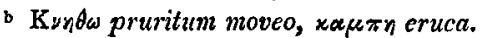

21. G. Everia, 
Species.

Icon.

21. G. Everia, Fab. .... Ernst, V. Pl. CLXXIX. f. 231. $\mathrm{a}-\mathrm{i}$.

22. - Lanestris, Linn.* Ernst, V. Pl. CLXXVIII. f. 230.

$a-f$

23. - Loti, Ochs. ...... Hübn. Bomb. Tab. 60. f. 256. (mas.) 257. (fœem.)

24. - Franconica, Fab. Ernst, V. Pl. CLXXXII, f. 234. $a-c$.

25. - Castrensis, Linn.† Ernst, V. Pl. CLXXXI. f. 233. a-l. Pl. CLXXXII. f. 233. $\mathbf{m}, \mathbf{n}$.

Curtis, Brit. Ent. V. Pl, 229. mas. foem. et larva.

26. - Neustria, Linn.†... Ernst, V. Pl. CLXXX. f. 232. a-n.

* Eriogaster, Germar, Steph.

" Palpi short, distinctly triarticulate, the basal joint longest and stoutest. the terminal minute, ovate, subacute; maxillce obsolete. Antennce bipectinated in the males, the pectinations decreasing in length to the apex, slightly serrated in the females : hoad small, pilose: thorax very stout, pilose above and below : abdomen robust and elongate in the females; moderate, and rather abbreviated in the males; densely clothed in both sexes with short down, and the apex in the female with a large woolly mass : wings elongate, entire, subdiaphanous, slightly reversed during repose : cilia short: legs short, femora and tibiæ densely clothed with wool. Larva gregarious cylindric, pilose, semi-annulated: pupa short, obtuse, not dentated at the apex, inclosed in a rigid, ovate cocoon." - Steph. Illust. Brit. Ent. Haustel. II. 44.

$\uparrow$ Clisiocampa, Curtis, Steph.

"Antennce inserted close to the eyes on the crown of the head, short, setaceous, bipectinated, the pectinations ciliated, long in the male, and gradplally decreasing in length to the apex, short in the female. Maxille and mandibles none. Labial palpi short, and very indistinet, being concealed by scales, the basal joint producing a fascicle of hairs beneath ; triarticulate ; 1 st joint rather robust; 2nd larger, elongateovate; 3rd minute oval. Males smaller than the females. Head very small and scarcely visible from above. Eyes globose. Thorax very robust. Abdomen short and small in the male, long robust and conical in the female. Wings deflexed when at rest, short in the males. Tibiæ anterior producing a broad compressed and pubescent lobe on the inside. Tarsi 5-jointed, basal joint the longest. Claws simple. Pulvilli distinct. Caterpillars with 6 pectoral, 8 abdominal, and 2 anal feet, cylindrical and hairy. Pupæ inclosed in a long silky cocoon."-Curtis, Brit. Ent. V. Pl. 229.

[To be continued.] 